\title{
Deficit in Leadership Qualities Negating Efforts in Curtailing Climate Change
}

\author{
Rasheed Adeniyi Tiamiyu ${ }^{1, *}$, Umar Taiwo Salman ${ }^{2}$ \\ ${ }^{1}$ Department of Bursary, The Polytechnic, Ibadan, Oyo State, Nigeria \\ ${ }^{2}$ Department of Electrical Engineering, King Fahd University of Petroleum \& Minerals, Saudi Arabia
}

Received July 1, 2021; Revised August 16, 2021; Accepted September 21, 2021

\begin{abstract}
Cite This Paper in the following Citation Styles
(a): [1] Rasheed Adeniyi Tiamiyu, Umar Taiwo Salman , "Deficit in Leadership Qualities Negating Efforts in Curtailing Climate Change," Environment and Ecology Research, Vol. 9, No. 5, pp. 215 - 223, 2021. DOI: 10.13189/eer.2021.090502.
\end{abstract}

(b): Rasheed Adeniyi Tiamiyu, Umar Taiwo Salman (2021). Deficit in Leadership Qualities Negating Efforts in Curtailing Climate Change. Environment and Ecology Research, 9(5), 215 - 223. DOI: 10.13189/eer.2021.090502.

Copyright $\bigcirc 2021$ by authors, all rights reserved. Authors agree that this article remains permanently open access under the terms of the Creative Commons Attribution License 4.0 International License

\begin{abstract}
Continuing generation of carbon dioxide by some nations in flagrant disobedient to the Paris Agreement of 2015 on greenhouse gas emission limitation is a matter of great concern to those who know the negative impact of climate change on the planet and human immunity in particular. The disobedient to the content of the Paris Agreement of 2015 is observed to be a resultant effect of deficit in the qualities of leaders of countries. Therefore, this paper examined the literature on climate change with a view to extracting what could be done to bring the nations acting against the interest of the world in limiting greenhouse gas generation to cooperate and collaborate with other nations in making the planet better for the living. It discovered that the collaborative efforts displayed by the World Health Organisation and individual nations in combating COVID-19 should be adopted to combat climate change as it has shown that no nation is independent of other nations in solving the problem of climate change since action/inaction of a nation has effects across the globe and that heads of countries must be educated and persuaded to be humane and relate with all human race as one to address climate change and make the planet a save abode for the livings.
\end{abstract}

Keywords Climate Change, COVID-19, Human Actions, Leadership Quality

\section{Introduction}

The world is facing challenges created by climate change caused by the actions of human being. Whereas, it has been long realised that human being requires a leader who would lead them to where they should be and not where they want to be because, majority of human being are not visionary and often time than not, they take decision on the present circumstances without consideration for the next and future circumstances which makes their present decision a disaster for their next needs. The inability of many to consider the future requirement has incredibly made human being to be aware that his actions on fossil fuel energy usage, which makes the greenhouse gases to be trapped to the atmosphere are the cause of rises in seas and extreme weather (climate change) which has negative consequential effect on the planet and the occupier of the earth but, the same human being could not drastically effect a change of life pattern because of the perceived immediate economic reasons and gains in fossil fuels. This practice which had being for decades long seemed to have been positively considered for change as there was a consensus in 2015 synthesizes by Intergovernmental Panel on Climate Change (IPCC) in Paris by the countries around the world that warming should be kept under 2 degrees Celsius. It was even agreed to pursue a lower range of 1.5 degrees Celsius but, this requires many of the leaders of the countries in the world to have leadership qualities to manage their countries to actualise the objectives of the agreement. Our observation has shown that the key player in the economy of the world had not shown a good example for others to follow as it is disheartening to note that neither of the set targets was attained according to the report of United 
Nations [1]. The said report which was brought to light at the last quarter of 2018 revealed that the estimated pollution expected to be around 25 and 55 percent in 2030 below the level we had in 2017 is very unlikely to be achieved, even, if the commitments made by countries in 2015 Paris agreements are now met. This means that the world should be prepared for the problems that would be generated by change in climate.

For example, flood to be instigated by the change in climate would negatively affect about 2.5 and 30 million people while $\$ 42$ and $\$ 79$ billion property would also be destroyed in coaster region and riverine areas respectfully [2]. The solutions in focus, as stated by [3], are, human re-orientation to adopt a climate friendly energy consumption which is cost effective and selling price is made affordable to the generality of the users. It is such a change that could guarantee the safety of forest which is undisputable source of oxygen being produced through its photosynthesis while the price of the source of energy polluting the atmosphere should increase beyond the reach of majority of the users.

The reported situation of the air pollution, notwithstanding, the pleasant news is that, it is on record that the conventional energy sector and its associated indices have witnessed a rapid decline in recent months. The decline had been attributed to the effect of the lockdown decision of countries which has slow-down economic activities in the world to curtail the spread of Covid-19 pandemic. Therefore, this paper is set to evaluate the perception and actions of some heads of countries as it relates to greenhouse gases emission and the lesson to be learnt from COVID-19 as a guide in an effort to curtail negative climate change.

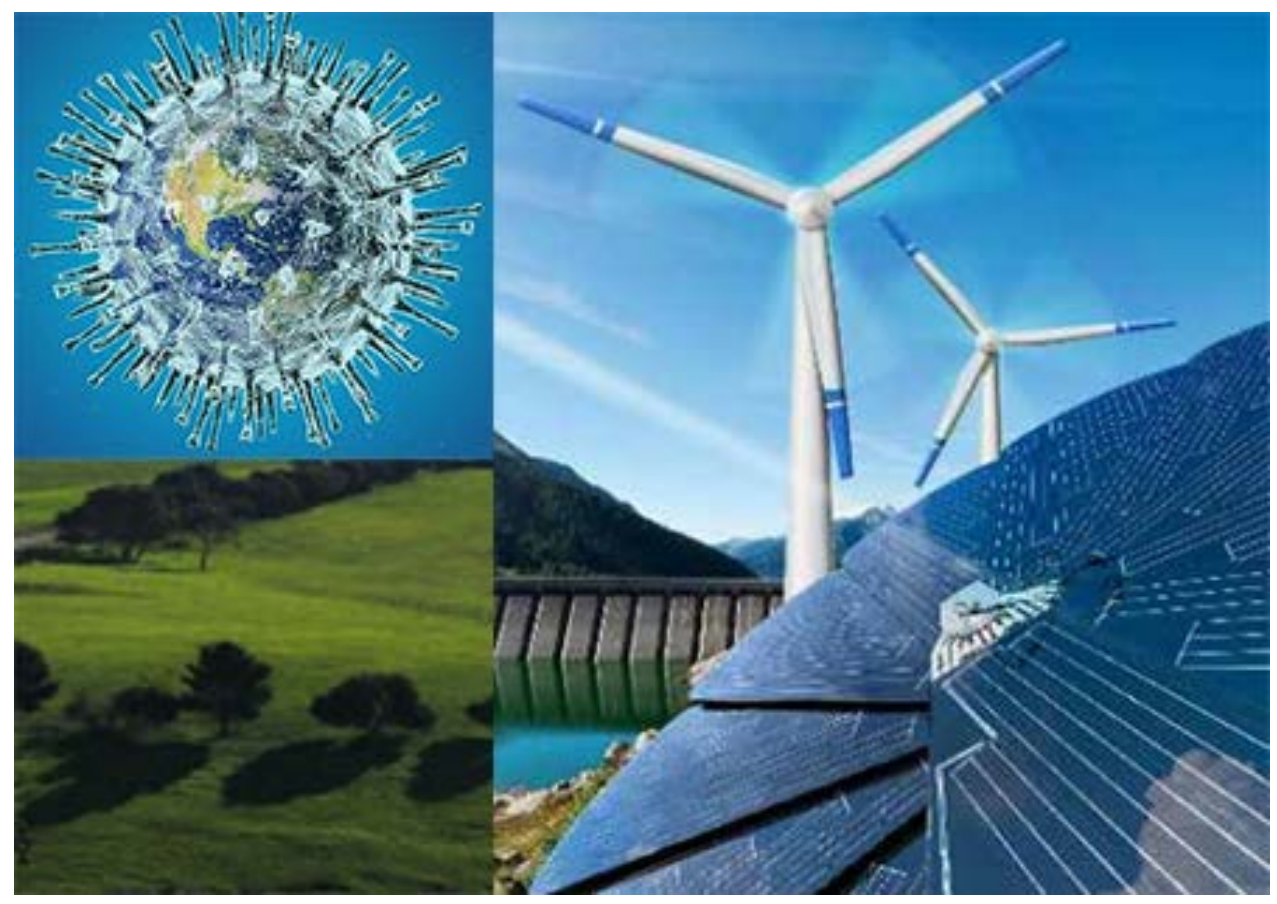

Figure 1. Covid-19 Pandemic energizing the growth of renewable energy. 


\section{Materials and Methods}

\subsection{Research Design}

This research adopted qualitative research methodology and made use of historical facts, content analysis of visual and textual materials to come up with the recommendations in this paper. This is in agreement with [4] and [5] that, in a complex world of ours, where perception is corollary of the depth of people reasoning and understanding of the matter, research method which would better their understanding is qualitative research method as its communication is unrestrained while results and implications of the data collected could be extracted simply. We submit that when research work entails critical analysis and evaluation of historical facts that has to do with perception and behavioural inclination of living being, qualitative research methods as adopted in this research is appropriate in the evaluation of the perception and actions of some heads of countries on the decision of United Nations (UN) to curtail greenhouse gas emission. Qualitative research methods would make the implication of the perception and actions of the heads of countries on curtailment of greenhouses gas emission clearer to the world with a view to providing advice on what could influence the heads of the countries to work together in the interest of the entire world.

\subsection{Methods}

This study was carried out to find out if there was leadership factor(s) militating against curtailment of usage of fossil fuels and therefore, reviewed literature on climate change with a view to extracting what could be done to bring the nations acting against the interest of the world in limiting greenhouse gas generation to cooperate and collaborate with other nations in making the planet better for the living.

\subsection{Factors Influencing Use Fossil Fuel}

Coal and gas, for the time being, due to its relatively low cost, would still be the source of power that would be providing electricity supply towards meeting the energy requirement of the world. For example, a significant part of the world requirement of electricity was stated to have been projected would still be sourced from coal and gas in 2040 [6]. This is still at the instance of the enhancement in the grow and development taking place in the renewable energies. Therefore, reliable and safe energy that would bring about a planet friendly energy may be assumed to be yet in sight except, the needful is done to make significant numbers of heads of countries appreciate the need for timely change in attitude on climate change. It is estimated that non-hydro energies which supplied 5 percent of the power produced in the world in 2012 may supply about thrice of it in 2040, [6]. It is also the opinion of International Energy Agency (IEA) as stated by [6] quoting Ibrahim Al Mannaee and Mona Hammami that the non-hydro renewables would have 17 percent of global electricity in 2040. It based its estimate on a projection that coal and natural gas which has 31 and 24 percent respectively of power supply would remain to be affordable and reliable source of energy. Therefore, fossil fuel would still be part of the 30 percent in the future because the trend of it to be so is already at sight. For example, Saudi Arabia which was the biggest oil supplier before was outmatched by United States of America which increased her production and brought about reduction in the prices of oil in 2014 and 2015. In the current estimate, it is estimated that Africa and Asia constitute the majority of people around 1.3 billion lacking electricity supply. This category of people would give much consideration to electricity that is most likely to be cheaper source of energy. It is also known that people without electricity would continue to make do with sources of energy like burning of wood and defecation of animal for cooking. It is believed that the air pollution being generated by the use of wood and dung for cooking is killing people than tuberculosis and malaria.

All-over the world, the awareness that when fossil fuel is burnt, it releases carbon dioxide and other greenhouse gasses to the atmosphere is now prime. Carbon emission from the use of petroleum products accounts for one third of the carbon emission in the world while coal burning is estimated to be generating carbon dioxide amounting to 44 percent of the global warming. As majority seems to be aware, it is no longer a struggle of scientists to convince people in the world that the problems the planet and the living being in it is facing now is due to air pollution from greenhouse gases but, the problem now, is how to make some heads of countries aligned the policy of their countries with the tenet of Paris Agreement of 2015. The inability of some organisations to align to the content of the agreement has led to the change in climate which was engineered by global warming instigated by heat being trapped in the atmosphere due to the usage of fossil fuels to generate power. This, the global warming, notwithstanding, there is still much to be done in educating those in authority since the climate change has not made some countries to be strongly committed to the tenet of the 2015 Paris Agreement. Therefore, the search now, is what could be done to educate those yet to be educated to curb the usage of fossil fuels.

\subsection{Challenges in Curbing Greenhouse Gases Requires Quality Leadership}

The world has long realised that sustainable energies could not be traced to or associated with coal, oil or gas which are fossil fuels and therefore, organisation and individuals have long started searching for the alternative 
to fossil fuels in renewable energies which is seen to be clean and friendly to the planet, [7]. To this end, some governments seem to be alive to the need to curb emissions as they consented to the 2015 Paris Agreement to curb usage of fossil fuels. The content of the agreement states that governments in the world have resolved to step-up efforts to reduce emissions of greenhouse gas which is due to the fossil fuels being used to generate power. They assert that, for the reduction in carbon dioxide to take place, they have to increase energy efficiency and replace fossil fuels with renewable energy. This, we observed, is easier said than done because, the power generating plants that have gulped a life savings of some governments and individual organisations are being operated on fossil fuels. This might be the reason why some individuals' organisation has considered diversion of the emissions from fossil fuel plants to the underground storage for recycling before they are released to the atmosphere as against outright steps toward purchasing renewable energy equipment. However, the high cost involves in capturing carbon dioxide from the smokestacks for recycling also made it unaffordable for majority to adopt. Scientist are, however, hopeful that advances in technology would make it affordable for majority in the near future. This, as it looks promising, would not be without its future challenges which are yet to be known due to its novelty. It is our view that, whatever is not natural would not be adequately friendly to a natural environment. There is no technology development without its challenges.

The challenges of renewable energy stem from its exorbitant cost as at now. For example, solar power plant that would generate $350 \mathrm{MW}$ at North Coast of Kent in UK would occupy 1,000 acres of land. Alternative to solar energy are biomass fuel, hydropower, geothermal energy and nuclear power. However, nuclear power also has high-radioactive waste while hydropower has negative impact /effect on aquatic species and terrestrial. The negatives in all these are, however, far lesser than negativities in the usage of fossil fuel.

The search for the planet friendly source of energy is an ongoing as Hydrogen is being worked upon by scientists. Scientists are also in unison on the need to plan beyond reduction in greenhouse gas emission to work on removing the pollution generated by greenhouse gasses which had already existed to enable cooling of the planet. The idea is called geoengineering schemes. They are of the view that the available options as at now are limited because majority of the options may pose more problem to the environment than what greenhouse gases emissions have done. What is not in controversy to assist human in clean-up substantial amount of carbon dioxide is trees plantation, restoration of seagrasses and increase in agricultural cover crops which are also matters to be engineered by leaders.

\subsection{Investment in Renewable Energy}

There has been some investment in renewable technologies between 2004 and 2015 of which countries like China, with 3 USD billion in 2004 has moved to 103 USD billion investment in renewable energies as at 2015 while Europe which has invested 123 USD billion in 2011 declined to 49 USD billion in 2015. If we are to base our opinion on the figure at hand as of now, China is seen to be the only single country having largest investment in renewables even more than Europe and United States of America taking together [8]. If China, India and their neighbour Asia and Oceania are combined, it is the largest continental investor in renewable energies. Investment in renewable energies in Middle East and Africa was 0.5 USD in 2004 but has started growing up in 2015. The research shows that all these developments reset on the leadership in place.

It is interesting to see that after the discovery of renewable energies, low and middle income transitioning economies are investing high percentage of their Gross Domestic Products (GDP) in renewables energies than high incomes nations. This is assumed to be due to a well-established energy system of fossil fuels in developed nations as against developing nations trying to build their energy sources from renewables. It means that low incomes countries get majority of their energies from renewables. They make use of biomass for heating and cooking while those that are categorised as advanced economy where better earnings are made are able to obtain their energy requirement from fossil fuel based energy sources. Except we have a visionary leader at the hem of affairs in developed counties, the fear is that some developed nations may embark on dumping their fossil fuel equipment to the developing nations at a ridiculously low price to attract their purchase.

\subsection{Curtailing Usage of Fossil Fuel}

As stated by [9], the high cost of oil in the 1950s and 1960s raised the interest in searching for alternative energies which had been seen in the solar power. In 1970s, the reports that were released spelt out how limited the oil resources in earth were. It stated that the oil resources would soon be depleted or increasingly expensive to extract. This assertion and in the real term, high cost of gas prices, couple with disaster in the nuclear plants made the demand for a safer energy to be on the increase. It was then discovered that solar and wind energies could be cost-effective and also environmentally friendly. However, experience had shown that it was the necessity which, usually instigated by crisis like war and great discomfort that, in most cases, brought about development and growth in technology advancement. For example, World War-11 brought about the process of coal, gas and oil into fossil fuels, (Gavin and Andrew 2010 as quoted by [10]. While we may not lay a strong hold on either of scarcities, 
shortages or war as the prime motivational factor in the efforts to look for alternative to fossil fuel, it is evidently noticed that many countries that are lucky to have visionary leaders at their helm of affairs have resolved to reduce carbon dioxide emissions. Among the notable countries that have resolved to shift to other sources of energy with a view to reducing their carbon emission are: German, Japanese, French and Danish as at the year 2020. There is also a group which was set up to research into how vehicles could be motioned with planet's friendly fuels with a view to reducing fossil fuel of GHG to $50 \%$ and petroleum to $20 \%$ of vehicles' consumption between now and 2050. In addition to this, is the technologies of nuclear power to reduce unfriendly emissions into the atmosphere.

Nuclear power development which began around 1930 by physicist Enrico Fermi was not visible to the public until 1942 when his team at University of Chicago succeeded for the first time, the presentation that neutrons could split atoms to achieve a chain reaction of nuclear explosion. In 1954, the success was followed by Soviet Union with the first production of electricity from atomic energy in the 51 at Experimental Breeder Reactor 1, Idaho while, 1957 was the year when commercialisation of nuclear power took place in the Shipping Port of Pennsylvania. Nuclear power is dependence on mining of substance (uranium in particular) which can be categorised as a finite product, therefore, nuclear power cannot be ordinarily categorised as renewable power but, because it is a power that does not emit any of the greenhouse gases, it is usually tagged with renewable energy even though its real categorisation should be considered under solution to climate change.

Nuclear power has shown that it has its own risk like any other equipment. The devastating effect of its accident was clear to the world as it occurred at Chernobyl in Ukraine, in 1986 and Fukushima Daiichi in 2011. As at today, the surrounding area where the plant exploded at Chernobyl is still an Exclusion Zone which is open to tourist but, inhabited by wildlife species while the evacuees of the Fukushima Daiichi plant mishap are still recovering after several years. The major issue, even if necessary precautionary measure is taken to prevent nuclear plant mishap, is storage of the used fuel or called it nuclear waste which is highly radioactive for the next thousand years and the need to site it close to water for cooling which will eventually lead to rising sea levels. Scientists are still working on fusion as against fission which is considered to deliver more energy but less radioactive property. All these possibilities require quality leader to take the most suitable option that serves the interest of the globe.

\subsection{Clog in the Growth of Renewable Energy}

Emergence of some leaders in some countries in the world has been clog in the wheel of progress in curtailment of greenhouse gasses usage. For example, when Donald Trump ascended the throne of the presidency of United States in 2016, he made it emphatically clear that he would not go along the way of his Predecessor-Barack Obama on 2015 Paris Agreement on climate change which Barack Obama signed. The rules in the agreement connote, among other things, that each country that signed the agreement could not signify intention to withdraw before November 4th 2019 and such notification would not have effect until one year after the signification of the intention. This then means that the formal notification to withdraw from the Paris Agreement by the United States of America as served in November 2019 would not be effective until November 4th, 2020. The said Paris Agreement also makes provision for the participating country to amend its National Determined Contribution upward not downward (Article 4.11) as against what United States of America was doing before November 4th 2020. It was observed that USA action was in contravention of the extant agreement and was glaringly directed toward politics and trade with no consideration, no matter how minute, to the global interest. The issue of the quality of leadership rekindled itself as enhancement in usage of fossil fuel was self-centred in satisfaction of a minute interest but creating a toxic environment which was killing the citizens of USA without them knowing and, by extension, world at large. The tragedy of this is that, there is little doubt that some countries would have followed the trend of USA action had it succeeded to generate more greenhouse gas to the disadvantage of the countries who refrain from generating more carbon dioxide emission because they, the leadership of those who restrain themselves from generating more carbon dioxide, see beyond the immediate gain in the air pollution activities. Those who refrain from pollution recognise the lifelong suffering from its attendant effect on the earth. Their refrain does not mean that they do not know the immediate economic gain they would make but, they subdued the shallow thinking which place immediate and unsustainable gain above long life benefits in the interest of all. For instance, [11], quoting Chen et al as saying that other countries of which developing nations who should ordinarily require assistant of the developed nations, would have to sacrifice their immediate but unsustainable benefits from fossil fuels usage and strive to use renewable energies to reduce the impact of the temperature emanating from the action of USA on greenhouse gas usage. As stated by the chief executive and the president of World Resources Institute, because the action of USA would make the planet toxic and unproductive for the livings. Andrew Steer that the move by USA administration under Donald Trump was cruel to the generation coming behind

For the world to steps toward the content of the Paris Agreement which is to pursue around 1.5-degree rise in 
temperature, every country in the world should not continue to generate carbon dioxide as much as it is generating now. Therefore, drawing from the action of the USA under Donald Trump as president which was overturned by the new administration of president Joe Biden on Friday 19 February, 2021, it could be said that some of the nations in the world are not strongly stepping toward renewable energy because of their current perceived economic advantage in fossil fuels.

\subsection{Pointer to Solution}

The advent of COVID-19 seems to be changing or redirecting the stepping as of now. According to Munjal in Energy World, 23 April, 2020, there is a relationship between the carbon dioxide in the environment and the confirmed cases of COVID-19 and he said he could not help think of urgent need for action on climate change. The current pandemic has necessitated measures that reduced operation of greenhouse emission around the globe because of lockdown and other measures taken by countries to curtail the spread of the virus. This has led to reduction in air pollution and rivers have begun to clean themselves while the night is becoming brightening. Finding solution to the problem in the pandemic has made human being realised that everyone needs each other to overcome the problem. The unity of purpose is increasing, animalistic instinct of self-centredness in human being is on the reduction, humanity is now evolving and, if sustained, the world would be at peace for all to enjoy. However, there are still challenges. According to [12], the unprecedented ravage in human life and economic activities which COVID-19 had inflicted has also brought doubt on the progress envisaged in the renewables. This is in addition to disappearance of sunshine, little or no breeze which is obstacle to energy generation by solar and wind equipment. There is no way solar and wind turbine equipment could generate energy when sun does not shine and breeze does not blow. Thus, to hope for a better post Pandemic era or a better managed impending subsequent wave of Covid-19 as being warned by scientists, there is need for leaders not deficient in leadership qualities to enable the world to direct its investment toward what would enhance healthy living and desist from hazardous economic activities [13]. Research has shown that climate change can have inimical effects on the immune system of living organisms. [14] found that the effect of temperature and carbon dioxide can alter the concentration of the ocean water leading to some level of acidification and which can negatively affect the immune response. A presentation in Washington D.C, [15] explained how climate change affects the immune system of mice demonstrating this in an experiment with mice living in heat and cold weather. He further explained that people often lose their immune system when they are ill. Adding that nutritional deficit resulting from prolonging the stoppage of enough feeding could weaken the immune system. Besides [16] have studied how global warming could catalyse the transmission of infectious diseases like Covid-19. Therefore, there is a strong justification to argue that immunity has something to do with global warming and consequently with renewable energy.

Renewable energy makes human being less vulnerable to infection and disease because it does not contribute to air pollution which is the major factor in climate change. It is important for the world to critically pursue the replacement of fossil fuels with renewables to revive the economy and at the same time make the environment friendly for the living. The report emanated from Harvard University revealed that cities where contamination is high portend a platform for high death of those infected by coronavirus (COVID-19) which is also a corroboration of the finding that the death of almost 2 to 4 million people could be linked to contaminated air.

COVID_19 has really opened up two possibilities for the world to choose from, after the pandemic might have been subdued by whatever means, the world may choose to reopen the economy which is powered by fossil fuel or jump-start the economy with determination to power the economy with renewable energy. What would influence how the world and particularly individual countries decide on the two options is dependent on the level of the interest it has in healthier society and unhealthy society of which the ultimate decision is a factor of the quality of leadership in place. The low electricity demand, due to lockdown instigated by Covid-19 control measures may force organisation using fossil fuels into closure due to their inability to generate sufficient income to match the cost of running their plant despite the oil price which is plummeting [17]. The pandemic (COVID-19) has led to a sharpest drop in the price of oil in a quarter of a century to such an extent that United States price of crude oil turned negative for the first time in history which may be an impetus for continuous usage of oil [18]. However, Solar Trade Association of United Kingdom, Chief Executive, Chris Hewett was quoted to have said that the government must not miss this golden chance to place renewables at the heart of the recovery. It was also observed in India that thermal power generation during March 2020 was down by $11.1 \%$ on last year's figure as fossil fuels bore the brunt of falling power demand due to lockdown caused by COVID-19 but, renewables-including hydro and nuclear have been unaffected due to their must-run status. Elsewhere, Italian Lender Intesa San Polo, amid Pandemic, recently awarded 12 unsubsidized solar projects worth 60 Million USD credit facility to the Canadian Solar [13]. Also, it is reported that Siemens is stepping actions towards ensuring good health and safe life in its development of the renewable energy plants and equipment for Covid-19. Moreover, another giant RE company based in Spain, Iberdrola has launched a new plan in (April 2020) called "Renewables vs Coronavirus", 
hiring up to 5, 000 new staff with an investment of 10.7 billion dollars on its $8.5 \mathrm{GW}$ renewable generation projects. The report of IEA also stated that renewables energy is the only power generation source which is experiencing rising demand and generation amid slump in energy demand brought on by COVID-19 industrial shutdown. This is obvious from the stimulus packages of some countries. For instance, Republic of Korea and China have 8 and 40 percent of their \$38 and \$586 billion stimulus package respectfully allotted to renewable energy development. This trend would bring about progressive development and grow in the economy and more employment opportunity would ensue for now and the coming years.

We hope the trend would continue as [19] climate change expert of United Nations Environmental Programme says, for now and future, human being and all the living being require environment which is devoid of carbon dioxide but built on planet friendly energy to protect all from the further threat of climate change. There is an urgent need for governments of the countries in the world to revisit the deadline set for the actualisation of renewable energy and strength their co-operation to achieve the objective set on climate sustainability, (The World Economic Forum 2020 and IRENA 2020 Government must have seen the benefits of renewable energy and continue to build public support for the transformation of societies into clean environment.

\section{Results}

The lockdown measures being implemented by each country in the world to curtail the spread of coronavirus (COVID-19) have constrained the operation of machines and equipment using fossil fuels and have significantly curtailed the emission of carbon dioxide which is the major cause of climate change.

Reduction in the usage of fossil fuels has led to glut in the oil industries and the market price of oil has fallen below its direct cost per barrel which is making usage of fossil fuels to be economically attractive to the industries making use of it.

The death rate in COVID-19 could not be directly linked to climate change but, it has been directly linked to the level of immunity of the infected. If it is not difficult to separate the climate change from the level of immunity of human being, it would be a difficult argument to say that what reduces the immunity in human being has no linkage with the death rate of the pandemic.

The pandemic, COVID-19 has brought majority of the world leaders together in an effort to halt the deadly virus for the first time. Though, the war against the pandemic is still on course as we write, the spirit of togetherness already established should be extended to the content of the 2015 Paris Agreement to retard global warming turning another pandemic which may turn the world to a non-living planet. We have seen that no nation is independent of other nations in solving the problem of climate change since action/inaction of a nation has effects across the globe and that heads of countries must be educated and persuaded to be humane and relate with all human race as one to address climate change and make the planet a save abode for the livings.

\section{Discussion}

The world should make use of the experience gained in the management of COVID-19 which has brought majority of the world leaders together for the first time in an effort to halt the deadly virus. The leaders in the world did realise that action or inaction of a country could bring about problem for the entire world. Their non-discriminatory action yielded positive result in curtailing the spread of the pandemic.

The enforcement of global policy on citizens of countries depends much on leadership. Therefore, it is of a significant importance to critically consider the catalyst effect of leaders' attitude to policy that has to do with initial sacrifices for the benefits of the future. Leadership quality, as could be seen, has significant impact on how the governed behave and react to policy. No matter how beneficial a policy might be, perception and reactions of the led to policy would be greatly influenced by the action of leader.

There is a glaring example from United State of America handling efforts of the governments in the entire world to address climate change, mainly, because of the personality of the person in the sit of presidency. When former President Barack Obama was in office, Paris agreement of 2015 was endorsed but, almost upturned by the administration of President Trump. It was the administration of President Joe Biden that reaffirmed the Paris Agreement of 2015 on climate change in 2021. The action of United State of America within the couple of years of changes in who occupies the presidential seat has demonstrated the effect of leadership quality in implementation of global decision on climate change. Leader should not be shallow in thinking and must not be self-centred.

The challenges of renewable energy stem from its exorbitant cost as at now. It is obvious that the negative effects of climate change are very unbearable and may lead to total destruction of what make living possible. Therefore, United Nations should consider subsidising the cost involves in producing climate friendly energy to make the price affordable to users.

\section{Conclusions and Recommendation}

It is strongly proposed that United Nations through the World Health Organisation should enhance educational aspect of its activities in educating the world leaders on 
the immediate and remote impact and effect of policies of government as it affects life of human being and other living beings which climate change is destructively doing now.

United Nations should consider subsidising the cost involves in producing climate friendly energy to make the price affordable to users. The selling price of climate friendly energy should be made affordable to the generality of the users.

There is urgent need for orientation of human being to adopt a climate friendly energy consumption.

Finally, human being in the world should ensure that they entrust the headship of their countries into the hands of those who have outgrown the animalistic tendencies of selfishness to lead them to where they should be and not where they, whimsically want to be.

\section{REFERENCES}

[1] Guterres A., "Forward” UN Climate Change Annual Report, pp. 4, 2018. https://webcache.googleusercontent.com/searc h?q=cache:HqnaiOucWCMJ:https://unfccc.int/sites/default /files/resource/UN-Climate-Change-Annual-Report-2018.p $\mathrm{df}+\& \mathrm{~cd}=1 \& \mathrm{hl}=$ en \&ct=clnk\&gl=ng\&client=firefox-b- $\mathrm{d}$ (accessed June 30, 2021)

[2] Layke J., Hutchinson N., "3 Reasons to Invest in Renewable Energy Now,” World Resources Institute (2020/04), https://www.wri.org/insights/3-reasons-invest-renewable-e nergy-now (accessed July 14, 2021).

[3] Nunez C., "Global warming solutions, do we have the will?”, National Geographic (2019), https://www.nationalg eographic.com/environment/article/global-warming-solutio ns (accessed July 14, 2021).

[4] Patton, M. "Qualitative evaluation and research methods" Designing Qualitative Studies 169 PURPOSEFUL SAMPLING. Beverly Hills, CA: Sage. 1990, pp. 169-186). https://pdf4pro.com/download/patton-m-1990-qualitative-e valuation-and-research-40cfdb.html (accessed July 14, 2021)

[5] Zeisel J., Bennett K., Fleming R., "Design, dignity, dementia: Dementia-related design and the built environment', is a global perspective of dementia-related design that takes a cross cultural approach, reflects regional and economic differences in low-, middle- and high-income ...”, The World Alzheimer Report 2020. https://www.alzint.org/resource/world-alzheimer-report-20 20/ (accessed July 14, 2021)

[6] Nyquist S., Manyik J., "Renewable energy: evolution, not revolution”, McKinsey Global Institute, March 24, 2016 https://www.mckinsey.com/industries/oil-and-gas/our-insi ghts/renewable-energy-evolution-not-revolution\# (accesse d July14, 2021)

[7] Simmonds P., "The Evolution of Renewable Energy”, EM Maggazine, April 16, 2019 https://www.energymanagerma gazine.co.uk/the-evolution-of-renewable-energy/ (accessed
July 14, 2021)

[8] Ritchie H., Roser M., "Fossil fuels”, Our world in data. Oct 2, 2017. https://ourworldindata.org/fossil-fuels?country= (accessed July 14, 2021)

[9] New Jersey Institute of Technology, "Evolution and Future Growth of Renewable Energy”, altenergymag.com, 06/17/14, 09:40 AM 2014. https://www.altenergymag.com /article/2014/06/evolution-and-future-growth-of-renewable -energy/1435/ (accessed July 14, 2021)

[10] Abas N., Kalair A., Khan N., "Review of fossil fuels and future energy technologies”. ScienceDirect, vol. 69., 31-49., 2015. https://www.sciencedirect.com/science/article/abs/pi i/S001632871500039.

[11] Jotzo F, Depledge J, Winkler H. "US and international climate policy under President Trump”. Taylor \& Francis Online, Volume 18, Issue 7, pp. 813-817, 2018. https://www.tandfonline.com/doi/full/10.1080/14693062.2 018.1490051 (accessed July 14, 2021)

[12] Nikolewski R. "Is the COVID-19 pandemic good news or bad news for renewable energy?" The San Diego Union Tribune, May 15, 2020. https://www.sandiegouniontribune .com/business/energy-green/story/2020-05-15/is-the-covid -19-pandemic-good-news-or-bad-news-for-renewable-ener gy (accessed July 14, 2021)

[13] Hall M. "Covid-19 weekly briefing: Evidence abounds of renewable energy gains at the expense of fossil fuels as the clamour for a green recovery rises”, PV Magazine, May 6, 2020. https://www.pv-magazine.com/2020/05/06/covid-19 -weekly-briefing-evidence-abounds-of-renewable-energy-g ains-at-the-expense-of-fossil-fuels-as-the-clamor-for-a-gre en-recovery-rises/ (accessed July 14, 2021)

[14] Hernroth B., Skold N. H., Wiklander K., Jutfelt F., Baden S., "Fish \& Shellfish Immunology:” Simulated climate change causes immune suppression and protein damage in the crustacean. Science Direct, Volume 33, Issue 5, Pages 1095-1101, November 2012. https://www.sciencedirect.co m/science/article/abs/pii/S1050464812002963

[15] Ichinohe, "Climate change can affect immune system:", South Asia's Leading Multimedia News Agency, Feb. 5, 2019. https://www.aninews.in/news/health/health/climatechange-can-affect-immune-system-study20190205111928/ (accessed July 14, 2021)

[16] Dobson, A., "Population dynamics of pathogens with multiple host species, the American naturalist” vol. 164, no. S5, pp. S64 - S78. 2004. DOI 10.1086/424681. https://pubmed.ncbi.nlm.nih.gov/15540143/\#heading

[17] Paull S. H. D. E., Horton M., Ashfaq D., Rastogi L. D., Kramer N. S., Diffenbaugh A., Kilpatrick M., "Drought and immunity determine the intensity of westnile virus epidemics and climate change impacts", Proceedings of the Royal Society B: Biological Sciences, vol. 284, no.1848, p. 20, 2017. 162078 .

[18] Williamson M., Zaman A., "COVID-19 crisis reinforces the importance of the sustainable energy transition”. UN ESCAP, 27 April 27, 2020. https://www.unescap.org/blog/ covid-19-crisis-reinforces-importance-sustainable-energy-t ransition

[19] Radka M. "Transforming the energy system-a 
post-COVID-19 win-win for people and planet”. UN

Environment Programme Story, 29 Apr 2020. https://www.unep.org/news-and-stories/story/transforming -energy-system-post-covid-19-win-win-people-and-planet 